\title{
Mussel selectivity for high-quality food drives carbon inputs into open-coast intertidal ecosystems
}

\author{
Matthew E. S. Bracken ${ }^{1,2, *}$, Bruce A. Menge ${ }^{3}$, Melissa M. Foley ${ }^{4}$, \\ Cascade J. B. Sorte ${ }^{5}$, Jane Lubchenco ${ }^{3}$, David R. Schiel ${ }^{6}$ \\ ${ }^{1}$ Marine Science Center, Northeastern University, 430 Nahant Road, Nahant, Massachusetts 01908, USA \\ ${ }^{2}$ Bodega Marine Laboratory, University of California-Davis, PO Box 247, Bodega Bay, California 94923, USA \\ ${ }^{3}$ Department of Zoology, Oregon State University, Corvallis, Oregon 97331-2914, USA \\ ${ }^{4}$ Center for Ocean Solutions, 99 Pacific Street, Suite 155A, Monterey, California 93940, USA \\ ${ }^{5}$ Department of Environmental, Earth and Ocean Sciences, University of Massachusetts-Boston, 100 Morrissey Blvd., \\ Boston, Massachusetts 02125, USA \\ ${ }^{6}$ School of Biological Sciences, University of Canterbury, Private Bag 4800, Christchurch 8140, New Zealand
}

\begin{abstract}
Filter-feeding invertebrates consume phytoplankton and detritus and therefore serve as important mediators of the exchange of materials from nearshore pelagic to intertidal benthic ecosystems. Here, we evaluated the linkages between nearshore and intertidal systems on temperate rocky reefs on the coasts of Oregon, USA, and New Zealand's South Island. We used differences in the concentrations of both nearshore particulate organic carbon and chlorophyll $a$ (chl a), a proxy for phytoplankton availability, at different sites in Oregon and New Zealand to evaluate the influences of suspended particulate organic material (POM) quality and quantity on the rates of carbon inputs associated with intertidal mussels (Mytilus californianus in Oregon and Mytilus galloprovincialis in New Zealand). We also analyzed the carbon stable isotope ratios $\left(\delta^{13} \mathrm{C}\right)$ of intertidal mussels and nearshore POM to examine changes in mussel growth in carbon relative to changes in their potential food sources along gradients of POM quality (i.e. carbon-tochlorophyll ratios, C:chl a). In both Oregon and New Zealand, the $\delta^{13} \mathrm{C}$ in mussel tissues did not change along a gradient of food quality, whereas the $\delta^{13} \mathrm{C}$ of the POM declined as food quality declined (i.e. C:chl a increased), suggesting that mussels were selectively consuming high-quality food. We also found that the availability of phytoplankton, a high-quality component of the POM, was a better predictor of mussel growth in carbon $\left(\mathrm{mg} \mathrm{C} \mathrm{g}^{-1} \mathrm{~d}^{-1}\right)$ than the total concentration of particulate organic carbon, which includes both higher-quality phytoplankton and lower-quality detrital material. Our results highlight the necessity of considering POM quality while evaluating the role of filter-feeders as mediators of carbon inputs into intertidal systems.
\end{abstract}

KEY WORDS: Benthic-pelagic coupling · Intertidal $\cdot$ Mussel $\cdot$ Mytilus $\cdot$ Particulate organic carbon · Phytoplankton $\cdot$ Growth $\cdot$ Spatial subsidies $\cdot$ Stable isotope

\section{INTRODUCTION}

In coastal ecosystems, early experiments and observations were focused on how local-scale processes operating within a particular system, especially 'top-down' trophic interactions, determined the structure and dynamics of benthic marine communities (Menge 1992). However, more recent work has highlighted the importance of external subsidies of propagules, nutrients, and prey (Polis et al. 1997). These inputs, which are typically associated with processes operating at larger spatial scales, can also 
strongly influence community structure and dynamics (Bustamante et al. 1995, Menge et al. 2003, 2004). For example, mytilid mussels, which are common inhabitants of many temperate rocky shorelines worldwide (Seed 1969, Koehn 1991), consume particulate organic material (POM), linking larger-scale processes in the nearshore environment with localscale, community-level processes at a particular intertidal location. Here, we focus on the role that mussels play as a conduit for carbon inputs into intertidal ecosystems and evaluate potential environmental factors underlying the magnitudes of these spatial subsidies.

Because ecological and physiological processes vary with environmental conditions, the roles that organisms play as mediators of spatial subsidies depend on the environmental context. For example, Menge et al. $(2003,2004)$ have shown that rates of growth, predation, and competition are higher in locations where bottom-up subsidies of food and nutrients, associated with coastal upwelling and hydrodynamics, are greater. Here, we use a comparative-observational approach (cf. the 'comparativeexperimental approach'; Menge et al. 2002) to explicitly evaluate the context-dependency of the role of mussels as mediators of carbon fluxes in 2 similarly structured, but independently evolved, ecosystems. Specifically, we quantified potential environmental determinants of mussel growth in carbon $(\mathrm{mg} \mathrm{C}$ $\mathrm{g}^{-1} \mathrm{~d}^{-1}$ ) along the coasts of Oregon, USA, and the South Island of New Zealand.

Previous work on these coastlines suggested that ecological processes at different locations are strongly influenced by differences in coastal oceanography operating at meso-scales (e.g. sites separated by $\sim 1$ to $100 \mathrm{~km}$ on different headlands within a region) and macro-scales (e.g. upwelling versus downwelling regimes spanning hundreds of kilometres; Menge et al. 2003, 2004). Briefly, the Oregon coast, part of the California Current System, is characterized by intermittent upwelling of cold, nutrient-rich water during the summer months, and the strength of upwelling increases from north to south (Menge et al. 2004, Broitman et al. 2008). The local availability of phytoplankton and particulate organic matter is influenced by the interactions between macro-scale processes, such as upwelling, and meso-scale attributes, such as headlands (Graham \& Largier 1997), river inputs (Hill \& Wheeler 2002), and the width of the continental shelf (Menge et al. 1997).

Variation in carbon and phytoplankton availability around the South Island of New Zealand is associated with 2 contrasting oceanographic regimes, an intermittent upwelling region associated with the Westland Current on the west coast and a persistent downwelling region associated with the Southland Current along the east coast (Stanton 1971, 1976, Vincent et al. 1991, Stanton \& Moore 1992, Menge et al. 2003, Schiel 2004). Within these macro-scale regimes, meso-scale factors, such as headlands, gyres, and terrestrial inputs, influence the quality and quantity of carbon sources available to intertidal filter feeders (Menge et al. 2003, McLeod \& Wing 2007, 2009).

Thus, on both the Oregon coast and the west coast of New Zealand, intermittent upwelling fuels nearshore phytoplankton production, and those phytoplankton can be transported back onshore when upwelling ceases (Bakun 1990, Menge et al. 2003, 2004), providing high-quality food that is readily consumed and assimilated by mussels (Coe \& Fox 1942, Newell \& Shumway 1993). Other forms of particulate organic material, including offshore phytoplankton, terrestrially derived particulate organic carbon (POC), and macroalgal detritus, are also potentially important subsidies to filter feeding invertebrates in intertidal systems (Duggins et al. 1989, Miller et al. 2008, Tallis 2009). Substantial river inputs result in high loads of terrestrially derived inputs of particulate organic material in both locations (Vincent et al. 1991, Hill \& Wheeler 2002). However, whereas terrigenous POC concentrations can be comparable to or even greater than those associated with phytoplankton blooms (Hill \& Wheeler 2002), terrestrial material is largely refractory and difficult to consume and assimilate (Mann 1988). In contrast, particulate organic detrital material derived from kelps and other macroalgae can provide high-quality food for filter-feeding invertebrates (Duggins et al. 1989, Bustamante \& Branch 1996, Tallis 2009), although offshore kelp beds were absent at our sites in both Oregon and New Zealand (M. Bracken pers. obs.).

We evaluated particulate concentrations within each geographic region (Oregon and New Zealand) to quantify and compare the influences of particulate quantity (i.e. total carbon concentrations) and quality (i.e. chlorophyll a $[\mathrm{chl} a]$ concentrations and carbonto-chlorophyll ratios [C:chl a]) on the magnitudes of mussel (Mytilus californianus Conrad in Oregon and Mytilus galloprovincialis Lamarck in New Zealand) roles in mediating carbon inputs into intertidal ecosystems. Specifically, we evaluated whether total POC (consisting of both detritus and phytoplankton) or chl a concentrations (an index of the availability of high-quality food, especially phytoplankton) were 
better predictors of mussel growth in carbon. Because POC typically includes low-quality (e.g. terrestrially derived material) and high-quality (e.g. phytoplankton) POM in nearshore environments, we predicted that mussel growth would be more closely associated with chl a than with total POC.

\section{MATERIALS AND METHODS}

\section{Study sites}

We measured characteristics of mussels (growth rates, \% $\mathrm{C}$ in tissue, and tissue carbon stable isotope ratios) and particulate organic material ( $\mathrm{chl} a$, POC concentrations, C:chl $a$, and POM carbon stable isotope ratios) at 10 wave-exposed rocky intertidal sites in Oregon and 12 similarly exposed open-coast sites in New Zealand. The Oregon sites ranged from Cape Meares $\left(45.49^{\circ} \mathrm{N}, 123.98^{\circ} \mathrm{W}\right)$ in the north to Rocky Point $\left(42.72^{\circ} \mathrm{N}, 124.47^{\circ} \mathrm{W}\right)$ in the south and spanned $475 \mathrm{~km}$ of coastline (Fig. 1, Table 1). In New Zealand, our 5 sites on the west coast of the South Island ranged from the mouth of the Nile River $\left(41.90^{\circ} \mathrm{S}, 171.44^{\circ} \mathrm{E}\right)$ in the north to Jackson Bay $\left(43.97^{\circ} \mathrm{S}, 168.61^{\circ} \mathrm{E}\right)$ in the south, spanning $325 \mathrm{~km}$, and our 7 sites on the east coast of the South Island ranged from the mouth of Blue Duck Creek $\left(42.28^{\circ} \mathrm{S}, 173.75^{\circ} \mathrm{E}\right)$ to Sandfly Bay on the Otago Peninsula $\left(45.90^{\circ} \mathrm{S}, 170.64^{\circ} \mathrm{E}\right)$ spanning $475 \mathrm{~km}$ (Fig. 1, Table 1). All sites were characterized by mid-intertidal mussel beds (including the congeners Mytilus californianus in Oregon and $M$. galloprovincialis in New Zealand) on rocky reefs. Variation in nearshore oceanographic conditions (e.g. Menge et al. 2003, 2004) affected the quality

A) Oregon sites

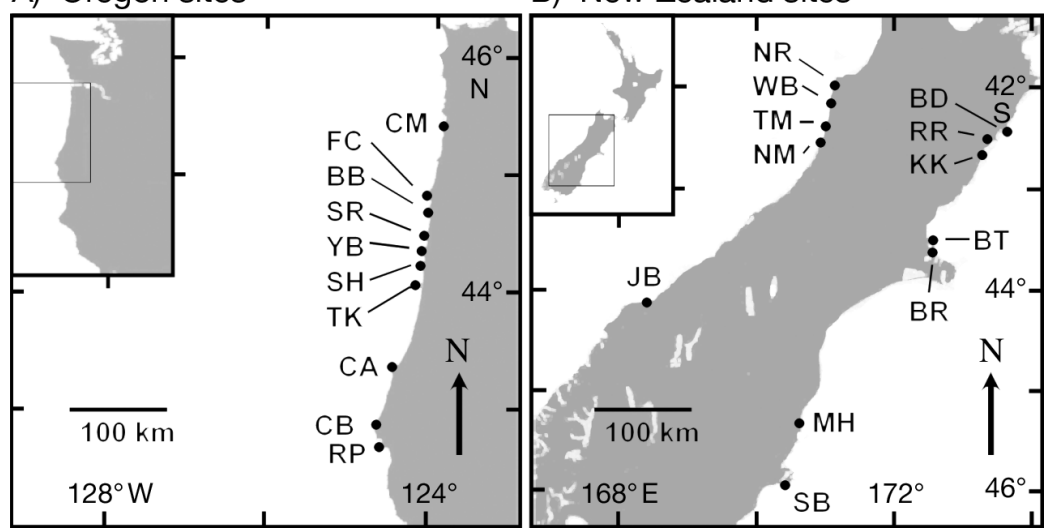

Fig. 1. Sampling locations on the coasts of (A) Oregon, USA, and (B) New Zealand. See Table 1 for site abbreviations and quantity of POC, allowing us to evaluate the factors that influenced the roles of mussels as mediators of carbon inputs into intertidal ecosystems.

\section{Water-column particulate organic material}

At each site, we collected water samples and measured total POC $\left(\mathrm{mg} \mathrm{l}^{-1}\right), \mathrm{chl} a\left(\mu \mathrm{g} \mathrm{l}^{-1}\right), \mathrm{C}: \mathrm{chl} a(\mu \mathrm{g}$ $\left.\mu \mathrm{g}^{-1}\right)$, and carbon stable isotope ratios $\left(\delta^{13} \mathrm{C}, \%\right)$. We visited sites monthly during the boreal summer (May through September) of 2003 in Oregon and twice per month during the austral spring and summer (October through January) of 2003 and 2004 in New Zealand. Samples were taken by filling 5 acid-washed opaque plastic (high-density polyethylene) brown bottles at $\sim 0.5 \mathrm{~m}$ depth in well-mixed water at low tide. We filtered $50 \mathrm{ml}$ from each sample bottle through a $25 \mathrm{~mm}$ Whatman glass-fiber filter (GF/F). These filters were transported to the laboratory on ice and analyzed for chl a using a Turner Designs benchtop fluorometer after extraction in $90 \%$ HPLC acetone for $24 \mathrm{~h}$ at $-20^{\circ} \mathrm{C}$ (Welschmeyer 1994). In the field, we also filtered $100 \mathrm{ml}$ through a $25 \mathrm{~mm}$ preashed Whatman GF/F filter from 3 bottles at each site for POC analysis. We transported these filters to the laboratory on ice, dried them $\left(50^{\circ} \mathrm{C}\right.$ for $\left.72 \mathrm{~h}\right)$, acid fumed them to remove carbonate, and analyzed the organic matter trapped on them for total carbon and $\delta^{13} \mathrm{C}$ using a PDZ Europa ANCA-GSL elemental analyzer interfaced to a PDZ Europa 20-20 isotope ratio mass spectrometer (Sercon) at the UC Davis Stable Isotope Facility. The resulting carbon-isotopic signatures were expressed as $\delta^{13} \mathrm{C}$ values per mille (\%), defined as $\delta^{13} \mathrm{C}=\left(R_{\text {sample }} / R_{\text {standard }}-1\right) \times 1000$, where $R$ is ${ }^{13} \mathrm{C}:{ }^{12} \mathrm{C}$, and the standard was Pee Dee Belemnite limestone. The long-term standard deviation for the instrument was $0.2 \%$.

We verified that chl a was a reasonable proxy for phytoplankton concentrations by collecting water samples from a subset of our Oregon sites (Boiler Bay, Strawberry Hill, Cape Arago, and Cape Blanco; Table 1) during the summer of 2001. In addition to filtering $50 \mathrm{ml}$ for chl a analysis as described above, unfiltered water samples were preserved with Lugol's solution, and counts were made of $1 \mathrm{ml}$ samples using a Sedgewick Rafter counting cell. Values presented are based on the average of 5 random transects across each sample grid. 
Table 1. Characteristics (means of all samples collected) of water-column particulate organic material at sites in Oregon, USA, (summer 2003) and New Zealand (summer of 2003 and 2004). Values are means (with standard errors). Chl a: chlorophyll a; POC: particulate organic carbon, $\delta^{13} \mathrm{C}$ : carbon stable isotope ratio

\begin{tabular}{|c|c|c|c|c|c|c|}
\hline Site & Latitude & Longitude & $\begin{array}{c}\text { Chl a } \\
\left(\mu \mathrm{g} \mathrm{l}^{-1}\right)\end{array}$ & $\begin{array}{c}\text { POC } \\
\left(\mathrm{mg} \mathrm{l}^{-1}\right)\end{array}$ & $\begin{array}{c}\text { C:chl a } \\
\left(\mu g \mu g^{-1}\right)\end{array}$ & $\begin{array}{c}\delta^{13} \mathrm{C} \\
(\% \text { \%) }\end{array}$ \\
\hline \multicolumn{7}{|l|}{ Oregon } \\
\hline Cape Meares (CM) & $45.49^{\circ} \mathrm{N}$ & $123.98^{\circ} \mathrm{W}$ & $8.0(1.3)$ & $1.0(0.0)$ & $151.8(28.0)$ & $-20.4(0.3)$ \\
\hline Fogarty Creek (FC) & $44.84^{\circ} \mathrm{N}$ & $124.05^{\circ} \mathrm{W}$ & $6.2(2.6)$ & $0.9(0.3)$ & $172.2(22.2)$ & $-20.9(0.7)$ \\
\hline Boiler Bay (BB) & $44.83^{\circ} \mathrm{N}$ & $124.06^{\circ} \mathrm{W}$ & $5.4(1.3)$ & $0.8(0.2)$ & $154.5(15.4)$ & $-21.0(0.8)$ \\
\hline Seal Rock (SR) & $44.50^{\circ} \mathrm{N}$ & $124.09^{\circ} \mathrm{W}$ & $27.1(7.6)$ & $2.2(0.5)$ & $107.5(21.8)$ & $-19.6(0.7)$ \\
\hline Yachats Beach (YB) & $44.31^{\circ} \mathrm{N}$ & $124.11^{\circ} \mathrm{W}$ & $127.0(54.4)$ & $4.6(2.2)$ & $67.5(18.6)$ & $-18.9(1.0)$ \\
\hline Strawberry Hill (SH) & $44.25^{\circ} \mathrm{N}$ & $124.11^{\circ} \mathrm{W}$ & 36.1 (12.6) & $2.6(0.7)$ & $102.9(18.0)$ & $-19.3(0.8)$ \\
\hline Tokatee Klootchman (TK) & $44.21^{\circ} \mathrm{N}$ & $124.12^{\circ} \mathrm{W}$ & $43.8(15.8)$ & $2.6(0.6)$ & $89.8(13.7)$ & $-19.4(0.7)$ \\
\hline Cape Arago (CA) & $43.31^{\circ} \mathrm{N}$ & $124.40^{\circ} \mathrm{W}$ & $3.3(1.3)$ & $0.5(0.1)$ & $221.7(42.6)$ & $-21.0(0.5)$ \\
\hline Cape Blanco (CB) & $42.84^{\circ} \mathrm{N}$ & $124.56^{\circ} \mathrm{W}$ & $7.2(1.0)$ & $0.9(0.1)$ & $148.0(42.5)$ & $-20.8(0.4)$ \\
\hline Rocky Point (RP) & $42.72^{\circ} \mathrm{N}$ & $124.47^{\circ} \mathrm{W}$ & $4.3(1.2)$ & $1.0(0.0)$ & $237.2(40.4)$ & $-20.7(0.5)$ \\
\hline \multicolumn{7}{|l|}{ New Zealand } \\
\hline \multicolumn{7}{|l|}{ West Coast } \\
\hline Nile River (NR) & $41.90^{\circ} \mathrm{S}$ & $171.44^{\circ} \mathrm{E}$ & $2.1(0.3)$ & $1.2(0.2)$ & $687.4(67.3)$ & $-25.1(0.5)$ \\
\hline Woodpecker Bay (WB) & $42.02^{\circ} \mathrm{S}$ & $171.38^{\circ} \mathrm{E}$ & $2.6(0.2)$ & $1.1(0.1)$ & $437.7(47.6)$ & $-24.6(0.5)$ \\
\hline Twelve Mile (TM) & $42.33^{\circ} \mathrm{S}$ & $171.27^{\circ} \mathrm{E}$ & $1.9(0.1)$ & $1.2(0.1)$ & $609.4(35.8)$ & $-25.3(0.4)$ \\
\hline Nine Mile (NM) & $42.34^{\circ} \mathrm{S}$ & $171.26^{\circ} \mathrm{E}$ & $3.4(0.5)$ & $1.4(0.2)$ & $422.6(19.7)$ & $-25.1(0.5)$ \\
\hline Jackson Bay (JB) & $43.97^{\circ} \mathrm{S}$ & $168.61^{\circ} \mathrm{E}$ & $1.7(0.4)$ & $1.4(0.4)$ & $748.9(40.7)$ & $-26.2(0.3)$ \\
\hline \multicolumn{7}{|l|}{ East Coast } \\
\hline Blue Duck (BD) & $42.28^{\circ} \mathrm{S}$ & $173.75^{\circ} \mathrm{E}$ & $1.4(0.1)$ & $0.8(0.1)$ & $597.9(36.8)$ & $-25.0(1.0)$ \\
\hline Raramai (RR) & $42.46^{\circ} \mathrm{S}$ & $173.55^{\circ} \mathrm{E}$ & $0.7(0.0)$ & $0.5(0.1)$ & $749.0(77.1)$ & $-26.0(1.0)$ \\
\hline Kie Kie (KK) & $42.46^{\circ} \mathrm{S}$ & $173.54^{\circ} \mathrm{E}$ & $0.8(0.0)$ & $0.6(0.1)$ & $726.7(57.5)$ & $-28.3(0.9)$ \\
\hline Box Thumb (BT) & $43.58^{\circ} \mathrm{S}$ & $172.78^{\circ} \mathrm{E}$ & $1.8(0.5)$ & $0.8(0.1)$ & $611.4(85.4)$ & $-24.7(0.9)$ \\
\hline Boulder Bay (BR) & $43.58^{\circ} \mathrm{S}$ & $172.80^{\circ} \mathrm{E}$ & $1.9(0.4)$ & $0.8(0.1)$ & $540.6(69.5)$ & $-24.8(0.8)$ \\
\hline Moeraki Harbor (MH) & $45.36^{\circ} \mathrm{S}$ & $170.80^{\circ} \mathrm{E}$ & $3.0(0.2)$ & $1.2(0.1)$ & $426.3(46.1)$ & $-21.2(0.6)$ \\
\hline Sandfly Bay (SB) & $45.90^{\circ} \mathrm{S}$ & $170.64^{\circ} \mathrm{E}$ & $1.1(0.1)$ & $0.7(0.1)$ & $640.4(41.2)$ & $-26.3(0.6)$ \\
\hline
\end{tabular}

Individual particulates were identified as phytoplankton, detritus, or inorganic material.

\section{Mussel growth}

We measured mussel growth rates by marking individuals in five $20 \mathrm{~cm} \times 20 \mathrm{~cm}$ mussel patches in the middle of the Mytilus zone at each site. Mussel densities were 1.6-fold higher in Oregon than in New Zealand ( $t=2.8$, df $=19, \mathrm{p}=0.012$ ) but did not differ between the east and west coasts of the South Island $(t=1.1, \mathrm{df}=10, \mathrm{p}=0.310)$. We carefully notched the posterior edge of every mussel in each patch with a triangular file. We collected mussels, with $19 \pm 2$ (mean $\pm \mathrm{SE}$ ) mussels recovered per patch, 1 yr later and measured the initial length from the umbo to the notch and the final length from the umbo to the posterior edge (Menge 2000, Menge et al. 2008). To determine the relationship between shell length and mass, we collected additional un-notched mussels from each site across a broad range of shell lengths, measured the shell length of each mussel, and dried the tissue from each mussel at $50^{\circ} \mathrm{C}$. We determined the relationship between dry tissue mass and shell length at each site and used the change in length of the marked mussels to calculate the annual rate of growth in dry biomass at that site. Whole mussel tissue $(\mathrm{n}=3$ randomly selected individuals from each site) was ground to a fine powder and analyzed for carbon (\%) and $\delta^{13} \mathrm{C}(\%)$, as described above for POM samples, at the UC Davis Stable Isotope Facility. We then calculated mussel growth in carbon (mg $\mathrm{C}^{-1} \mathrm{~d}^{-1}$ ) by multiplying the average annual in situ growth rate (mg dry tissue $\mathrm{g}^{-1} \mathrm{~d}^{-1}$ ) by the proportion of carbon in the tissues of the mussels collected at each site.

We measured the height of each mussel patch above mean lower-low water to verify that differences in elevation, which could potentially be associated with differences in access to particulates while submerged, did not underlie differences in growth. This was especially important for sites in New Zealand, where immersion times could differ on the east and west coasts. In Oregon, the average plot heights were $1.82 \pm 0.12 \mathrm{~m}$ (mean $\pm \mathrm{SE}$ ). In New 
Zealand, the average plot heights at sites on the east coast (mean \pm SE: $0.93 \pm 0.09 \mathrm{~m}$ ) were no different than those on the west coast $\left(0.93 \pm 0.11 \mathrm{~m}_{i} t=0.1\right.$, $\mathrm{df}=10, \mathrm{p}=0.955$ ).

\section{Statistical analyses}

General linear models (GLMs), including analyses of variance and regressions, were used to evaluate differences among sites in the relationships between water-column POM attributes (i.e. chl $a$, POC, C:chl $a_{\text {, and }} \delta^{13} \mathrm{C}_{i}$ Table 1) and mussel growth in carbon. For all analyses, the sample unit was the site, and the mean values recorded at each site were used. Use of site means was necessary because the attributes we measured describe processes that are known to integrate over different temporal scales. By averaging all values for each site and using those means in our analyses, we reduced the contribution of highly variable (e.g. associated with upwelling and downwelling), short-term measures (e.g. chl $a$ and C:chl a) so that their scale of variation matched longer-term measures, like $\delta^{13} \mathrm{C}$ (weeks to months) and growth in carbon (annual). We also ensured that we sampled a variety of conditions at each location to capture a range of POM and mussel attributes at each site. GLM assumptions of normality and homogeneity of variances were verified by visually examining residual plots and normal probability plots of the residuals. In all cases, the data from Oregon and New Zealand were analyzed separately.

We used the corrected Akaike information criterion $\left(\mathrm{AIC}_{\mathrm{c}}\right)$ to assess the relative effectiveness of various models for explaining relationships in our dataset (Burnham \& Anderson 2002). $\mathrm{AIC}_{\mathrm{c}}$ compares model fits, penalizing models with more factors; lower (including more negative) $\mathrm{AIC}_{\mathrm{c}}$ values indicate better fits. The difference $\left(\Delta_{i}\right)$ between each model's $\mathrm{AIC}_{\mathrm{c}}$ and that of the best-fitting model was then used to calculate the relative likelihood $\left(w_{i}\right)$ of each model as the best approximation of the data. We used these calculations to compare the effectiveness of chl a versus POC for describing mussel growth.

\section{RESULTS}

\section{Predictors of mussel growth}

Attributes of water-column POM varied substantially across sites in both Oregon and New Zealand (Table 1), and we used these gradients in particulate quality and quantity to evaluate potential factors associated with the growth of intertidal mussels. In particular, we examined whether annual rates of growth in carbon $\left(\mathrm{mg} \mathrm{C} \mathrm{g}^{-1} \mathrm{~d}^{-1}\right)$ were best explained by the average amount of total POC or chl a measured at a given site. The counts from the preserved samples of particulate materials indicated that chl a was unrelated to the amount of detritus in water samples $\left(F_{1,14}=0.2, \mathrm{p}=0.675, \mathrm{R}^{2}=0.01\right)$. Instead, chl $a$ increased with the number of phytoplankton cells $\left(F_{1,14}=10.9, \mathrm{p}=0.005, \mathrm{R}^{2}=0.44\right)$. Both chl a (Oregon: $F_{1,7}=142.2, \mathrm{p}<0.001 ;$ New Zealand: $F_{1,10}=9.7, \mathrm{p}=$ 0.011; Fig. 2) and POC (Oregon: $F_{1,7}=57.3, \mathrm{p}<0.001$; New Zealand: $F_{1,10}=7.7, \mathrm{p}=0.020$ ) were positively associated with mussel growth in Oregon and New Zealand (Fig. 2), and POC and chl a were correlated with each other (Oregon: $F_{1,8}=98.7, \mathrm{p}<0.001, \mathrm{R}^{2}=$ 0.93; New Zealand: $F_{1,10}=16.6, \mathrm{p}=0.002, \mathrm{R}^{2}=0.62$ ). However, in both Oregon and New Zealand, chl a was a better predictor of mussel growth in carbon, based on the $\mathrm{AIC}_{\mathrm{c}}$ for chl a versus POC (Table 2). The ratios of the Akaike weights, which indicate the likelihood of each candidate model, show that chl a was 68 -fold (= 0.986/0.014; Table 2$)$ more likely than POC to explain mussel growth in Oregon and 1.7-fold $(=0.631 / 0.369)$ more likely to explain mussel growth in New Zealand. Furthermore, in both Oregon and New Zealand, after accounting for the effects of chl a (i.e. in a multiple regression including both chl $a$ and POC), the POC availability had no effect on growth in carbon (Oregon: $F_{1,6}=0.1, \mathrm{p}=0.812$; New Zealand: $F_{1,9}=0.6, \mathrm{p}=0.478$ ). Tide height had no effect on mussel growth in either Oregon $\left(F_{1,7}<0.1\right.$, $\mathrm{p}=0.949)$ or New Zealand $\left(F_{1,10}=0.7, \mathrm{p}=0.421\right)$.

\section{Selection of high-quality food by mussels}

The relationship between chl $a$ and mussel growth suggested that mussels were feeding selectively on phytoplankton. We assessed the selectivity of mussel feeding by quantifying changes in both mussel and POC carbon stable isotope ratios along gradients of POC quality $(\mathrm{C}: \mathrm{chl}$ a) in Oregon and New Zealand. The $\delta^{13} \mathrm{C}$ of the POM declined as C:chl a increased (Oregon: $F_{1,8}=20.4, \mathrm{p}=0.002 ;$ New Zealand: $F_{1,10}=$ 12.38, $\mathrm{p}=0.006$; Fig. 3), but we observed no change in the $\delta^{13} \mathrm{C}$ of the mussels with increasing C:chl a (Oregon: $F_{1,8}=0.0, \mathrm{p}=0.847$; New Zealand: $F_{1,10}=$ $1.3, \mathrm{p}=0.277$; Fig. 3 ), suggesting that mussels were selectively incorporating a constant carbon source, despite changes in the carbon source of the POM upon which they were feeding. 

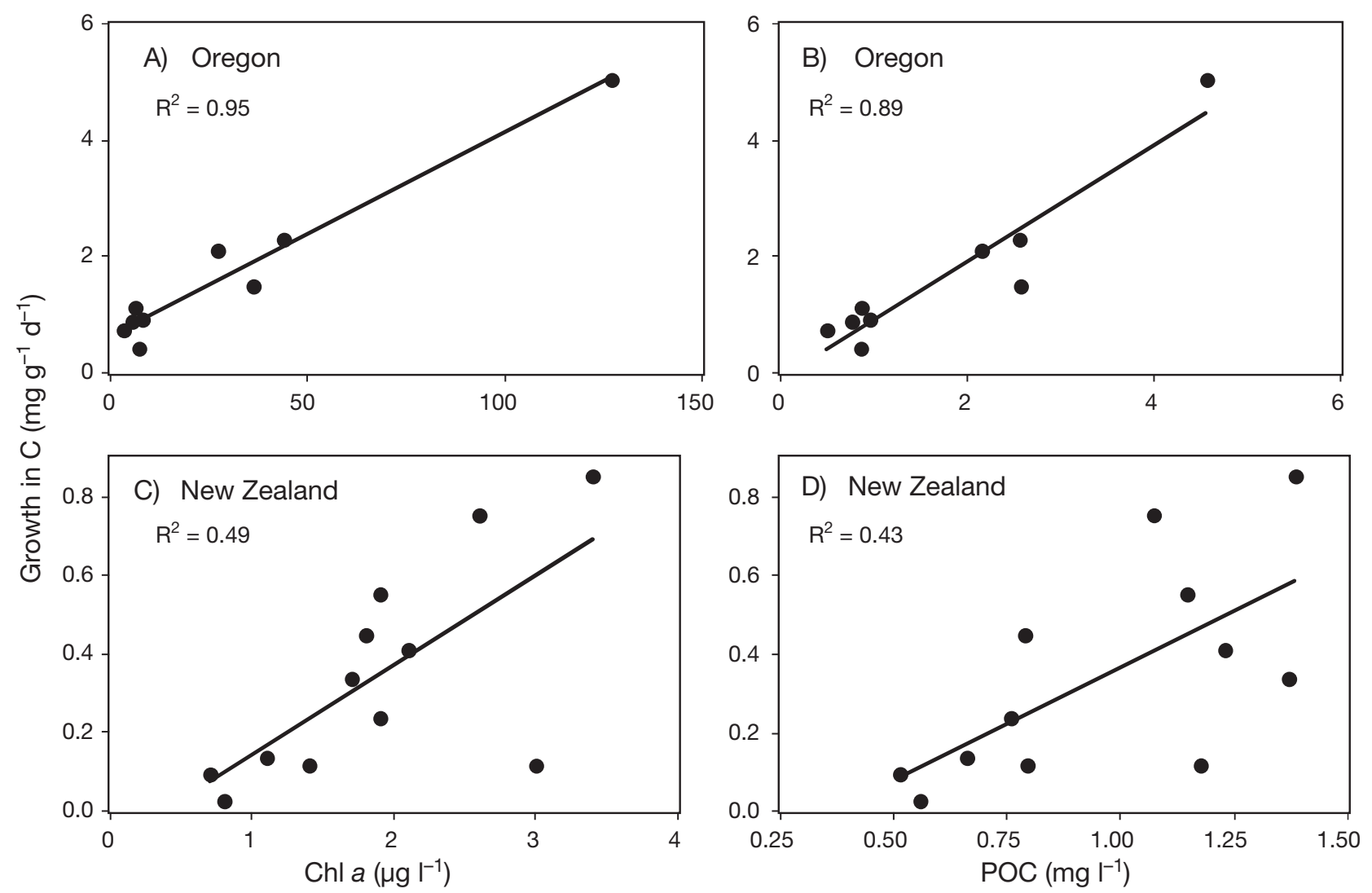

Fig. 2. Mytilus californianus and M. galloprovincialis. Mussel growth in carbon $\left(\mathrm{mg} \mathrm{C}^{-1} \mathrm{~d}^{-1}\right)$ increased with both chlorophyll a (chl a) and particulate organic carbon (POC) concentrations. Both (A) chl a $(\mathrm{p}<0.001)$ and (B) POC (p < 0.001) were positively associated with mussel growth in Oregon, USA. Similarly, both $(C)$ chl a $(p=0.011)$ and $(D) P O C(p=0.020)$ were positively associated with mussel growth in New Zealand. However, fits for chl a were better than for POC in both Oregon and

New Zealand. Note differences in scales between panels

Table 2. Comparison of models describing the effects of phytoplankton (chlorophyll a [chl a]) versus carbon as factors explaining mussel growth $\left(\mathrm{mg} \mathrm{C} \mathrm{g}^{-1} \mathrm{~d}^{-1}\right)$. AIC : corrected Akaike information criterion; lower (i.e. more negative) values indicate better model fits. $\Delta_{i}$ : difference between the bestfitting model and the model presented; $w_{i}$ : Akaike weights indicating the probability that a given model is the best fit

\begin{tabular}{|lccc|}
\hline Model & $\mathrm{AIC}_{\mathrm{c}}$ & $\Delta_{i}$ & $W_{i}$ \\
\hline Oregon & & & \\
Chl $\mathrm{a}\left(\mu \mathrm{l}^{-1}\right)$ & -20.3 & 0.0 & 0.986 \\
Carbon $\left(\mathrm{mg} \mathrm{l}^{-1}\right)$ & -11.8 & 8.4 & 0.014 \\
New Zealand & & & \\
Chl $a\left(\mu \mathrm{l}^{-1}\right)$ & -26.2 & 0.0 & 0.631 \\
Carbon $\left(\mathrm{mg} \mathrm{l}^{-1}\right)$ & -25.1 & 1.1 & 0.369 \\
\hline
\end{tabular}

\section{DISCUSSION}

Given the presence, and often dominance, of mussels on temperate mid-intertidal rocky shores worldwide (Seed 1969, Paine 1974, Castilla \& Duran 1985,
Koehn 1991, Menge et al. 2003, Hill et al. 2006), understanding the roles these filter feeders play in mediating carbon inputs is essential to our understanding of coupling between nearshore and rocky intertidal ecosystems. Here, we investigated factors underlying mussel growth in carbon in 2 sets of open-coast rocky intertidal ecosystems, those of Oregon, USA, and the South Island of New Zealand. In particular, our use of the comparative-observational approach, conducting identical observations in 2 regions on opposite sides of the Pacific Ocean, allowed us to evaluate the generality of factors influencing the role of mussels in converting POC into tissue carbon, which is subsequently available to organisms at higher trophic levels (e.g. Newell \& Field 1983)

We evaluated whether either the total average amount of available carbon (POC) or high-quality carbon ( $\mathrm{chl}$ a) were better predictors of mussel growth in carbon. Mussels can consume both detritus and phytoplankton. In some systems, including ones 


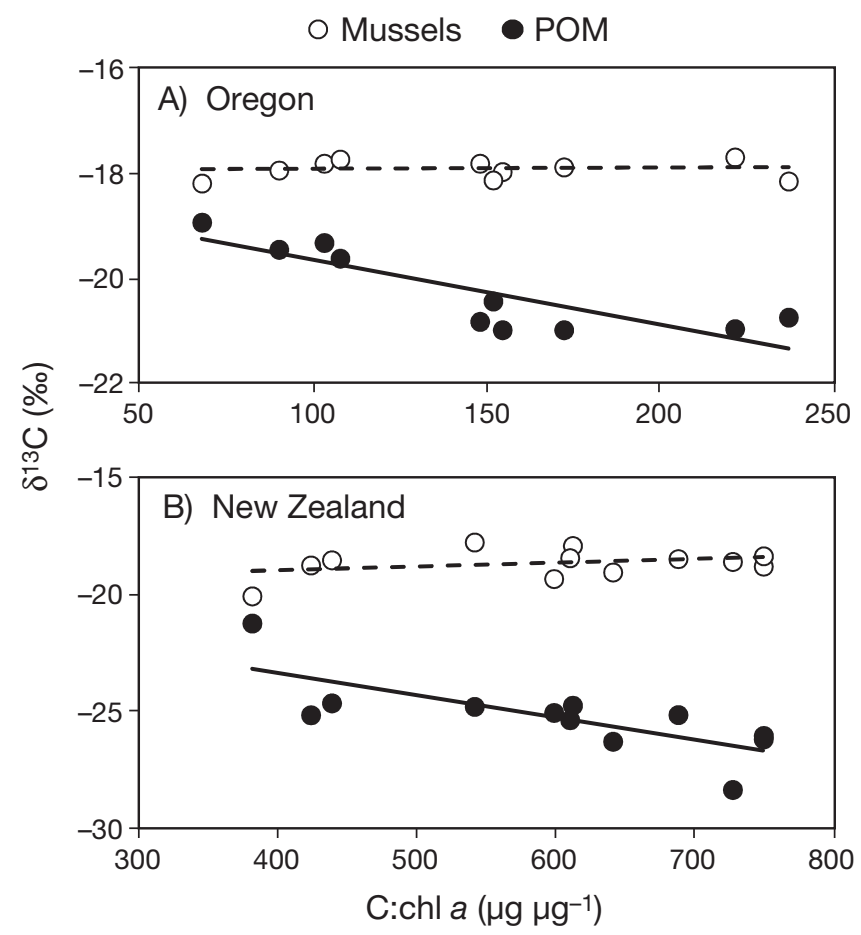

Fig. 3. Mytilus californianus and M. galloprovincialis. Selectivity of mussel feeding across gradients of particulate organic matter (POM) quality (carbon-to-chlorophyll a [C:chl a]). In both (A) Oregon, USA, $(p=0.001)$ and $(B)$ New Zealand ( $p=$ $0.006)$, as $\mathrm{C}$ :chl a increased, the $\delta^{13} \mathrm{C}$ signature of the POM ( and solid regression lines) declined. However, in both Oregon and New Zealand, the mean isotopic signature of mussels at those sites ( $\mathrm{O}$ and dashed regression lines) remained constant across the gradient of POM quality (Oregon: $p=0.233$, New Zealand: $\mathrm{p}=0.277$ )

dominated by the 2 species we evaluated here, e.g. Mytilus californianus on the coasts of Washington (Tallis 2009) and California (M. Foley unpubl. data) and M. galloprovincialis on the coast of South Africa (Bustamante \& Branch 1996, Hill et al. 2006)), nonphytoplankton POC can represent the majority of the carbon consumed by mussels. In contrast, the growth of mussels at our sites was most closely associated with chl a (Fig. 2, Table 2), which was a good surrogate for phytoplankton abundances. However, chl a concentrations were unrelated to the amount of particulate detrital material.

One difference between the results of our study and those of earlier studies that highlighted the importance of kelp detritus was the decline in $\delta^{13} \mathrm{C}$ signatures that we observed at our sites in both Oregon and New Zealand as C:chl $a$ increased. C:chl $a$ is an index of the relative abundance of phytoplankton and detritus in a water sample; values for 'pure' phytoplankton range from 20 to $120 \mu^{\prime}{\mu g^{-1}}^{-1}$ Eppley 1968, Banse 1977). Higher values are indicative of a mixture of phytoplankton and detrital material, with increasing values of $\mathrm{C}$ :chl $a$ associated with a greater detrital component in the POM. In Alaska (Duggins et al. 1989) and South Africa (Bustamante \& Branch 1996, Hill et al. 2006), increases in the availability of macroalgal detritus were associated with increases in $\delta^{13} \mathrm{C}$, as kelp and other macroalgae typically have a more enriched $\delta^{13} \mathrm{C}$ signature than phytoplankton.

The declines in $\delta^{13} \mathrm{C}$ that we observed as $\mathrm{C}: \mathrm{chl} a$ increased (Fig. 3) are consistent with 2 possible explanations. First, a decrease in $\delta^{13} \mathrm{C}$ could be explained by an increase in the terrestrial material in the POC (Page et al. 2008), as the $\delta^{13} \mathrm{C}$ of terrestrial material ( -24.7 to $-31.3 \%$; Richard et al. 1997, Maksymowska et al. 2000, Tallis 2009) tends to be more negative than that of either phytoplankton (-17.4 to $-26.7 \%$; Richard et al. 1997, Maksymowska et al. 2000, Cloern et al. 2002, Miller et al. 2008) or macroalgal detritus (-12.0 to $-17.7 \%$; Duggins et al. 1989, Bustamante \& Branch 1996). Second, on the Oregon shelf, inshore phytoplankton have elevated $\delta^{13} \mathrm{C}$ values relative to offshore phytoplankton (Miller et al. 2008). Thus, as chl $a$ increases (and C:chl a correspondingly declines), $\delta^{13} \mathrm{C}$ tends to increase due to a shift from small phytoplankton characteristic of offshore communities (i.e. photosynthetic eukaryotes $<5 \mu \mathrm{m}$ ) to larger phytoplankton (i.e. diatoms) characteristic of the inshore upwelling system (Sherr et al. 2005). Visual examination of our preserved phytoplankton samples from Oregon suggested that smaller phytoplankton, such as flagellates, only occurred at sites characterized by low chl a (e.g. Cape Arago), and previous work off the Oregon coast indicates that small phytoplankton can comprise a large fraction of the phytoplankton biomass when chl $a$ is low (Hood et al. 1992, Corwith \& Wheeler 2002). However, the relationship that we describe between phytoplankton abundances and chl a based on our preserved samples was almost entirely due to changes in the abundances of larger species, such as diatoms (M. Bracken pers. obs.).

Our data indicate that terrestrially derived material was likely an important component of the suspended POM, especially in New Zealand. With the exception of Moeraki Harbour, all of the average POM $\delta^{13} \mathrm{C}$ values we measured in New Zealand were less than $-24.6 \%$ (Table 1), which is consistent with estimates of river- and terrestrially derived $\delta^{13} \mathrm{C}$ values measured on the coasts of Washington, USA (Tallis 2009), and Fiordland, New Zealand (McLeod \& Wing 2009). Combined with the low chl a concentrations and the high C:chl a values, the low $\delta^{13} \mathrm{C}$ values we observed in New Zealand coastal waters suggest that much of 
the POC may be terrestrial in origin. High rainfall on the west coast of the South Island and large rivers on the east coast deliver terrigenous material to the coastal ocean (Schiel 2004). Even in Oregon, where chl a concentrations can be very high (e.g. an average of $127 \mu \mathrm{g} \mathrm{l}^{-1}$ at Yachats Beach), C:chl $a$ at some sites (i.e. Cape Arago, Rocky Point) exceeded $200 \mu \mathrm{g}$ ${\mu \mathrm{g}^{-1}}^{-}$, suggesting a relatively high proportion of detritus in the POM (Table 1). Furthermore, visual counts of preserved samples from our Oregon sites indicate that detrital material, much of which was clearly of terrestrial origin, can comprise an appreciable fraction of suspended particulates in the nearshore environment.

Terrestrial detritus is largely refractory, consisting of material such as cellulose and lignin that is difficult or impossible for many marine organisms to digest (Mann 1988, McLeod \& Wing 2007). Mussels are very effective at particle sorting, retaining highquality POM (e.g. diatoms and dinoflagellates), and rejecting low-quality POM (e.g. terrestrial detritus and flagellates; Coe \& Fox 1942, Bayne et al. 1993, Ward et al. 1997, Hawkins et al. 1998, Rouillon \& Navarro 2003). Our data highlight this selectivity in both Oregon and New Zealand. Sites characterized by higher C:chl a had lower POM $\delta^{13} \mathrm{C}$ values. However, the average $\delta^{13} \mathrm{C}$ signature of mussels was constant across sites within both Oregon and New Zealand (Fig. 3). Particularly in New Zealand, terrestrial material comprised a fraction of the available POC, but our data suggest that mussels selectively rejected this low-quality carbon in favor of highquality phytoplankton. The decline in $\delta^{13} \mathrm{C}$ with increasing $\mathrm{C}$ :chl $a$ in Oregon POM samples could also have been associated with shifts in phytoplankton community composition toward smaller species in areas where chl a tended to be lower (Sherr et al. 2005, Miller et al. 2008). However, mussels actively reject small flagellated phytoplankton, preferentially consuming diatoms (Rouillon \& Navarro 2003), which would also allow them to maintain a constant $\delta^{13} \mathrm{C}$ signature as POM quality changed.

Although the present data are limited in temporal scale (i.e. POM and mussel tissue samples collected over a single summer season in each location), our data highlight the need to consider both the quantity and quality of the suspended POM available to filterfeeders when evaluating factors underlying carbon inputs into intertidal ecosystems. In both Oregon and New Zealand, we have multiple years of data from some of these sites, including Boiler Bay, Strawberry Hill, Cape Arago, and Cape Blanco in Oregon and Woodpecker Bay, Twelve Mile, Raramai, and Box
Thumb in New Zealand. The relationships we describe here, including the effects of changes in POM quality and quantity on mussel growth and the relationships between $\mathrm{C}: \mathrm{chl} \mathrm{a}$ and the carbon stable isotope ratios of the POM and mussels, seem to be characteristic of those sites (M. Bracken unpubl. data). Particularly in Oregon, the strong relationship between phytoplankton availability and mussel growth suggests that either summer phytoplankton availability determined a substantial fraction of the annual growth in mussels during 2003 (e.g. Coe \& Fox 1942, 1944, Seed 1969) or that summer values were a reasonable proxy for annual food availability. Other factors, including temperature and tide height, can interact with phytoplankton availability to influence mussel growth (e.g. Menge et al. 2008). However, chl a explained virtually all of the among-site differences in growth observed in Oregon in 2003, and we found no relationship between tide height and growth in either Oregon or New Zealand. Incorporating information on water temperatures in future work could improve our understanding of the relative importance of chl $a$ in explaining variation in mussel growth, particularly in New Zealand, where chl a did not explain as much of the variance in growth (Fig. 2c).

On the wave-exposed shorelines that we studied in both Oregon and New Zealand, the role that mussels play in converting POC into tissue carbon (i.e. differences among sites in mussel growth in carbon) was more closely associated with chl a concentrations than with total POC concentrations (Fig. 2, Table 2). Together with previous work on these coastlines, our data suggest that coastal oceanographic and hydrodynamic processes determine the availability of high-quality phytoplankton (Menge et al. 1997, 2004), which influences the rate of carbon accumulation at the base of intertidal food webs. These carbon inputs provide energy for organisms at higher trophic levels, affecting the intensity of top-down control (Menge et al. 2003, 2004). Mussel-mediated carbon inputs therefore represent a bottom-up subsidy that shapes the structure and dynamics of these mussel-dominated, temperate, rocky-shore communities.

Acknowledgements. We are grateful to J. van Berkel (Edward Percival Field Station, Kaikoura, New Zealand) and S. Williams (Bodega Marine Laboratory, Bodega Bay, California, USA) for laboratory space. F. Chan, P. Jepson, D. Lytle, P. McEvoy, E. Sanford, and V. Weis provided essential feedback on this research. C. Cardoni, A. Carranza, F. Chan, A. Chaudoin, R. Dunmore, M. Dutton, M. Faubel, S. Lilley, R. Milston-Clements, J. Pamplin, L. Petes, P. Reynolds, J. 
Ridley, M. Robart, R. Russell, J. Sapp, D. Taylor, and S. Wood cheerfully assisted with field and laboratory work. Funding was provided by the National Science Foundation (grants OCE-0351778 to J. Stachowicz and OCE-0549944 to S. Williams and M.E.S.B.), Bodega Marine Laboratory institutional funds (to M.E.S.B.), the Andrew W. Mellon Foundation (to J.L., B.A.M., and D.R.S.), the Partnership for Interdisciplinary Studies of Coastal Oceans (PISCO; to J.L. and B.A.M.), and the New Zealand Foundation for Research, Science and Technology (to D.R.S.). This is contribution number 417 from PISCO, a long-term, large-scale ecological consortium funded by the David and Lucile Packard and the Gordon and Betty Moore Foundations, contribution number 283 from the Marine Science Center, Northeastern University, and a contribution from the Bodega Marine Laboratory, University of California, Davis.

\section{LITERATURE CITED}

Bakun A (1990) Global climate change and intensification of coastal ocean upwelling. Science 247:198-201

> Banse K (1977) Determining the carbon-to-chlorophyll ratio of natural phytoplankton. Mar Biol 41:199-212

> Bayne B, Iglesias J, Hawkins A, Navarro E, Heral M, Deslous-Paoli JM (1993) Feeding behaviour of the mussel, Mytilus edulis: responses to variations in quantity and organic content of the seston. J Mar Biol Assoc UK 73:813-829

Broitman BR, Blanchette CA, Menge BA, Lubchenco J and others (2008) Spatial and temporal patterns of invertebrate recruitment along the west coast of the United States. Ecol Monogr 78:403-421

Burnham KP, Anderson DR (2002) Model selection and inference: a practical information-theoretic approach, 2nd edn. Springer-Verlag, New York, NY

$>$ Bustamante RH, Branch GM (1996) The dependence of intertidal consumers on kelp-derived organic matter on the west coast of South Africa. J Exp Mar Biol Ecol 196: $1-28$

- Bustamante RH, Branch GM, Eekhout S, Robertson B and others (1995) Gradients of intertidal primary productivity around the coast of South Africa and their relationships with consumer biomass. Oecologia 102:189-201

> Castilla JC, Duran LR (1985) Human exclusion from the rocky intertidal zone of central Chile: the effects on Concholepas concholepas (Gastropoda). Oikos 45:391-399

> Cloern JE, Canuel EA, Harris D (2002) Stable carbon isotope composition of aquatic and terrestrial plants of the San Francisco Bay estuarine system. Limnol Oceanogr 47: 713-729

> Coe WR, Fox DL (1942) Biology of the California sea mussel Mytilus californianus. I. Influence of temperature, food supply, sex, and age on the rate of growth. J Exp Zool 90: $1-30$

$>$ Coe WR, Fox DL (1944) Biology of the California sea-mussel (Mytilus californianus). III. Environmental conditions and rate of growth. Biol Bull (Woods Hole) 87:59-72

Corwith HL, Wheeler PA (2002) El Niño related variations in nutrient and chlorophyll distributions off Oregon. Prog Oceanogr 54:361-380

Duggins DO, Simenstad CA, Estes JA (1989) Magnification of secondary production by kelp detritus in coastal marine ecosystems. Science 245:170-173

Eppley RW (1968) An incubation method for estimating the carbon content of phytoplankton in natural samples. Limnol Oceanogr 13:574-582

Graham WM, Largier JL (1997) Upwelling shadows as nearshore retention sites: the example of northern Monterey Bay. Cont Shelf Res 17:509-532

Hawkins AJS, Bayne BL, Bougrier S, Héral M and others (1998) Some general relationships in comparing the feeding ecology of suspension-feeding bivalve molluscs. J Exp Mar Biol Ecol 219:87-103

> Hill JK, Wheeler PA (2002) Organic carbon and nitrogen in the northern California current system: comparison of offshore, river plume, and coastally upwelled waters. Prog Oceanogr 53:369-387

Hill JM, McQuaid CD, Kaehler S (2006) Biogeographic and nearshore-offshore trends in isotope ratios of intertidal mussels and their food sources around the coast of southern Africa. Mar Ecol Prog Ser 318:63-73

Hood RR, Neuer S, Cowles TJ (1992) Autotrophic production, biomass and species composition at two stations across an upwelling front. Mar Ecol Prog Ser 83:221-232

Koehn RK (1991) The genetics and taxonomy of species in the genus Mytilus. Aquaculture 94:125-145

Maksymowska D, Richard P, Piekarek-Jankowska H, Riera $P$ (2000) Chemical and isotopic composition of the organic matter sources in the Gulf of Gdansk (southern Baltic Sea). Estuar Coast Shelf Sci 51:585-598

> Mann KH (1988) Production and use of detritus in various freshwater, estuarine, and coastal marine ecosystems. Limnol Oceanogr 33:910-930

McLeod RJ, Wing SR (2007) Hagfish in the New Zealand fjords are supported by chemoautotrophy of forest carbon. Ecology 88:809-816

> McLeod RJ, Wing SR (2009) Strong pathways for incorporation of terrestrially derived organic matter into benthic communities. Estuar Coast Shelf Sci 82:645-653

> Menge BA (1992) Community regulation: under what conditions are bottom-up factors important on rocky shores? Ecology 73:755-765

Menge BA (2000) Top-down and bottom-up community regulation in marine rocky intertidal habitats. J Exp Mar Biol Ecol 250:257-289

Menge BA, Daley BA, Wheeler PA, Dahlhoff E, Sanford E, Strub PT (1997) Benthic-pelagic links and rocky intertidal communities: bottom-up effects on top-down control? Proc Natl Acad Sci USA 94:14530-14535

> Menge BA, Sanford E, Daley BA, Freidenburg TL, Hudson G, Lubchenco J (2002) Inter-hemispheric comparison of bottom-up effects on community structure: insights revealed using the comparative-experimental approach. Ecol Res 17:1-16

> Menge BA, Lubchenco J, Bracken MES, Chan F and others (2003) Coastal oceanography sets the pace of rocky intertidal community dynamics. Proc Natl Acad Sci USA 100: 12229-12234

> Menge BA, Blanchette C, Raimondi P, Freidenburg T and others (2004) Species interaction strength: testing model predictions along an upwelling gradient. Ecol Monogr 74:663-684

Menge BA, Chan F, Lubchenco J (2008) Response of a rocky intertidal ecosystem engineer and community dominant to climate change. Ecol Lett 11:151-162

Miller TW, Brodeur RD, Rau GH (2008) Carbon stable isotopes reveal relative contribution of shelf-slope production to the Northern California Current pelagic community. Limnol Oceanogr 53:1493-1503 
Newell RC, Field JG (1983) The contribution of bacteria and detritus to carbon and nitrogen flow in a benthic community. Mar Biol Lett 4:23-36

Newell CR, Shumway SE (1993) Grazing of natural particulates by bivalve molluscs: a spatial and temporal perspective. In: Dame RF (ed) Bivalve filter feeders in estuarine and coastal ecosystem processes. Springer, Heidelberg, p 85-148

Page HM, Reed DC, Brzezinski MA, Melack JM, Dugan JE (2008) Assessing the importance of land and marine sources of organic matter to kelp forest food webs. Mar Ecol Prog Ser 360:47-62

Paine RT (1974) Intertidal community structure: experimental studies on the relationship between a dominant competitor and its principal predator. Oecologia 15:93-120

Polis GA, Anderson WB, Holt RD (1997) Toward an integration of landscape and food web ecology: the dynamics of spatially subsidized food webs. Annu Rev Ecol Syst 28: 289-316

Richard P, Riera P, Galois R (1997) Temporal variations in the chemical and carbon isotope compositions of marine and terrestrial organic inputs in the bay of Marennes-Oléron, France. J Coast Res 13:879-889

Rouillon G, Navarro E (2003) Differential utilization of species of phytoplankton by the mussel Mytilus edulis. Acta Oecol 24:S299-S305

Schiel DR (2004) The structure and replenishment of rocky shore intertidal communities and biogeographic comparisons. J Exp Mar Biol Ecol 300:309-342

Editorial responsibility: Steven Morgan,

Bodega Bay, California, USA
Seed R (1969) The ecology of Mytilus edulis L. (Lamellibranchiata) on exposed rocky shores. II. Growth and mortality. Oecologia 3:317-350

Sherr EB, Sherr BF, Wheeler PA (2005) Distribution of coccoid cyanobacteria and small eukaryotic phytoplankton in the upwelling ecosystem off the Oregon coast during 2001 and 2002. Deep-Sea Res II 52:317-330

Stanton BR (1971) Hydrology of Karamea Bight, New Zealand. NZ J Mar Freshw Res 5:141-163

> Stanton BR (1976) Circulation and hydrology off the west coast of the South Island, New Zealand. NZ J Mar Freshw Res 10:445-467

Stanton BR, Moore MI (1992) Hydrographic observations during the Tasman Boundary Experiment off the West Coast of the South Island, New Zealand. NZ J Mar Freshw Res 26:339-358

> Tallis H (2009) Kelp and rivers subsidize rocky intertidal communities in the Pacific Northwest (USA). Mar Ecol Prog Ser 389:85-96

> Vincent WF, Howard-Williams C, Tildesley P, Butler E (1991) Distribution and biological properties of oceanic water masses around the South Island, New Zealand. NZ J Mar Freshw Res 25:21-42

Ward JE, Levinton JS, Shumway SE, Cucci T (1997) Site of particle selection in a bivalve mollusc. Nature 390: 131-132

> Welschmeyer NA (1994) Fluorometric analysis of chlorophyll $a$ in the presence of chlorophyll $b$ and pheopigments. Limnol Oceanogr 39:1985-1992

Submitted: October 13, 2011; Accepted: April 16, 2012

Proofs received from author(s): July 2, 2012 